\title{
Tariff Issues of Network Transaction in China
}

\author{
Feng Ran \\ Guangdong University of Foreign Studies, International Trade and Economics Faculty \\ fengran@oamail.gdufs.edu.cn
}

Keywords: Network transaction; Internet Application; Tariff Policy

\begin{abstract}
With the Internet developed rapidly and computers applied widely, the "Computer World" has been being more mature and forming a pyramid structure with hardwares, Internet protocols, softwares, management rules and policies. Each part of the structure is important, especially the supervisory on the top. Therefore, this paper particularly concentrates on the tariff policies evaluation of China to promote the development of Internet application in cross-border e-commerce. Moreover, it also consider the "new" tarriff rule have many advantages comparing with "old" rules, such as promoting the development of B2B e-commerce, increasing the revenue of tariff and ect.
\end{abstract}

\section{The Development of Cross-Border E-commerce Tariff Policy of China}

\subsection{Postal Article Tax on Personal Items through Post and Express Delivery}

According to the traditional definition of China Customs, the term of Personal Postal Item was established at the old time of planned economy with a shortage of product supply, which was favorable for overseas Chinese and limited to the personal gifts to their relatives, being characterized by personal usage, acceptable amount, non-commercial usage and non-trading. According to 'the Notice of Adjusting the Limited Value and Tariff Exemption Amount of Personal Belongings in the Import and Export Mail' (File No. [1994]1774) issued by the Customs on November $14^{\text {th }}$, 1994, the value of personal belongings mailed from Hongkong and Macau region is limited to 800 RMB. Item of 400 RMB or below is given tariff exemption. Personal belongings imported from other countries and regions are limited to $1000 \mathrm{RMB}$ for each single mail. Item of $500 \mathrm{RMB}$ or below is given tariff exemption. Items above limit value should be applied customs clearance as trade goods. However, though above limited value, only one and inseparable item in single mail which is confirmed to be personal usage after the customs check can be applied clearance as personal belonging. Any mail of commercial item must be applied customs clearance as trade goods and relevant taxation procedures.

As the overseas purchasing on one's behalf continues to emerge, according to 'the Notice of Adjusting the Supervision Measures on the Personal Belongings in the Import and Export Mail' (File No. 43) issued by the General Administration of Customs of China in July 2010, the value limit of personal postal items from Hongkong and Macau and other countries remains unchanged but the tax exemption amount is reduced from $400 \mathrm{RMB}$ and $500 \mathrm{RMB}$ to $50 \mathrm{RMB}$ (including 50 $\mathrm{RMB}$ ) at all, which aims to restrict the import of products of on-line shopping and purchasing on one's behalf in the name of personal postal mail. 


\subsection{Trial Implementation of Postal Article Tax at Cross-Border E-commerce}

The E-commerce of China has entered a period of high speed development, which was encouraged by 'the Plans of Adjusting and Rejuvenating Logistics' (File No.6 [2009]) issued by the State Council in 2009, and the official approval of Alipay and other 27 companies in their business of third party electronic payment by the People's Bank of China in 2011. The number of internet users of on-line shopping has been largely increased by $40.95 \%$ of that in 2012 . In order to answer the call of e-commerce development and promote it to be the new drive of China's trade growth, National Development and Reform Commission issued 'the Special Notice of Establishing Pilot Cities of National E-commerce Demonstration' in May 2012, and approved Shanghai, Hangzhou, Ningbo, Guangzhou, Shenzhen, Chongqing, Zhengzhou and other cities to become the pilot cities in order. Local customs bureaus are responsible for providing appropriate plan to better supervise the development of cross-border e-commerce of China.

In July 2014, while concluding on the trial clearance experience of each local customs, for the first time, the General Administration of Customs has launched 'the Announcement of Supervision on the Import \& Export Goods and Items in Cross-border E-commerce' (File No. 56, 2014) (herein after called the Announcement ${ }^{[7]}$, which largely focused on the cross-border e-commerce. The Announcement not only stipulates on the qualification of companies in the cross-border e-commerce business that companies must conduct import and export trade on platform approved by the customs, but also defines trading goods and items in cross-border e-commerce. At the same time, the customs has different supervision upon trading goods and items. For example, enterprise should complete a list of trading goods or items, summarize the list by month and apply for the customs clearance which is characterized by 'list check, summary for application and one time clearance'.

On the other hand, for the first time, the Announcement defines the Direct Sales Import of Cross-border E-commerce (Direct Sales Import in short) and Bonded Import of Cross-border E-commerce (Bonded Import in short). Direct Sales Import means that products of on-line shopping are applied clearance as personal items, which request consumers to pay for the postal article tax besides the product price and delivery fee. Bonded Import means that the companies which have already registered in domestic market and customs system and complied with interconnection with the information system of customs and other relevant departments procure overseas products and apply for customs clearance on the basis of 'the whole cargo inward and the single piece outward' at the bonded area, which means that the whole cargo of products enter the area as trading goods, and then each single piece leaves the area as personal belonging. Two modes of import have similar tariff calculation and application procedures. According to regulations of 'the Notice of Adjusting the Supervision Measures on Personal Items in the Import and Export Mail' (File No. 43) issued by the General Administration of Customs of China in 2010, when collecting the postal article tax in the mode of Direct Sales Import, product of value below 1000 RMB for each single import is applied customs clearance as personal item, where the postal article tax is calculated on the sales price of electronic order. For products with import tax of $50 \mathrm{RMB}$ or below, the postal article tax is exempted by the customs. Imported products of $1000 \mathrm{RMB}$ or above are applied clearance as trading goods, where tariff should be applied on the basis of import origin and product category. Imported products above $1000 \mathrm{RMB}$ can be also applied clearance as personal items in the case that single import mail contains only one and inseparable personal item which is confirmed after customs check.

In addition, the annual import value of buying personal use items for each Chinese citizen is limited to 20 thousand RMB. Product value within 20 thousand RMB is applied the personal postal article tax but the exceeding part is applied relevant tariff and added value tax. With reference to the 
products of bonded import, on the basis of 'Personal Usage and Reasonable Amount', the Announcement regulates that imported product below $1000 \mathrm{RMB}$ is applied clearance as personal belonging and postal article tax. Product above 1000 RMB is applied clearance as trading goods and relevant tariff.

Table 1: Personal postal article tax of imported goods of the People's Republic of China from 2012 to 2016 .

\begin{tabular}{ll}
\hline Item Name & $\begin{array}{l}\text { Tax } \\
\text { Rate\% }\end{array}$ \\
\hline $\begin{array}{l}\text { Foods (including milk powder and healthcare product), drinks, } \\
\text { publication, books and newspaper, lantern slide, educational movie, video }\end{array}$ \\
$\begin{array}{l}\text { camera recorder, video tape, original tape, gold, silver and finished } \\
\text { product, calculator, camera, digital camera and other information technical }\end{array}$ \\
$\begin{array}{l}\text { product, other products not included in the list of the following No.2, } 3 \\
\text { and } 4 \text { taxation categories and remarks }\end{array}$ \\
$\begin{array}{l}\text { Textile and finished product, bicycle, watch, clock (including parts and } \\
\text { accessories), TV video recorder and other electrical appliances }\end{array}$ \\
3 High-end watch (more than 10000 RMB), golf ball and gear \\
4 Cosmetic, cigarette and alcohol & $30 \%$ \\
\hline
\end{tabular}

Note: 'Categories of Imported Goods of the People's Republic of China' (File No. 15, 2012) issued by the General Administration of Customs and implemented from April 15 ${ }^{\text {th }}, 2012$

\subsection{Comprehensive Tax of Cross-Border E-commerce}

In order to further improve the supervision, according to 'the Announcement of Imported Product List of Cross-border E-commerce Retail Sales' (File No. 40, 2016) jointly issued by the Ministry of Finance and other 11 ministries ${ }^{[8]}$, the Customs issued 'the Announcement of Supervision on the Import \& Export Goods and Items in Cross-border E-commerce Retail Sales' (File No.26, 2016), which stipulates that the latest import list of cross-border e-commerce retail sales includes 1142 products in 8 taxation categories, and products must be consumer products of daily living imported by express delivery and post and compatible with supervision, such as garment, shoes, hat, maternal and baby product, home appliance and some cosmetics. Products within the list can be exempted from providing approval certificate to customs, but still need to complete quality and quarantine inspection according to the national legal regulation, where direct sales Import and bonded import differ from each other. Product of direct sales import is exempted from inspection upon the clearance list. On the other hand, product of bonded import must comply with the inspection upon clearance list as trading goods when entering the bonded area but not necessary when leaving the area. In addition, the range of products in the list keeps adjusted according to the development of cross-border e-commerce and change of consumer demand. ${ }^{[1]}$

With reference to tariff collection, according to 'the Notice of Import Taxation Policy of Cross-border E-commerce Retail Sales' (File No.18, 2016) jointly issued by the Ministry of Finance, General Administration of Customs and State Administration of Taxation, the No. 26 Announcement names the concept of 'Comprehensive Tax of Cross-border E-commerce' to replace the postal article tax in 2014. As Comprehensive Tax of Cross-border E-commerce collects zero tariff from imported product of cross-border e-commerce, according to the regulations of general import trade, imported product is applied $70 \%$ of the add-value tax plus consumption tax (detailed tax rate in Table 3), in which the duty-paid price is calculated by combining actual transaction price, domestic delivery fee and insurance fee. At the same time, the No. 26 Announcement removes the 
regulation of the No.56 Announcement in 2014 that product with tax amount of 50 RMB or below is exempted from taxation, and the annual value limit of 20 thousand RMB for individual imported product of cross-border e-commerce retail sales remains unchanged. However, the limit of single transaction value rises from $1000 \mathrm{RMB}$ to $2000 \mathrm{RMB}$. If single transaction is over limit, or the total accumulated amount exceeding individual annual limit, the product is applied clearance as general trading goods and full amount taxation. Within 30 days after the customs clearance, imported product of cross-border e-commerce retail sales can be applied procedures of returns of goods, tax refund and deduction of individual annual transaction amount.

Table 2 Comparison between comprehensive tax and postal article tax of common cross-border imported products after April 6th, 2016.

\begin{tabular}{|c|c|c|c|c|}
\hline \multirow{2}{*}{ Product Name } & \multicolumn{3}{|c|}{$\begin{array}{l}\text { Import Comprehensive Tax of } \text { Cross-border } \\
\text { E-commerce of } 2016 \\
\text { (added value tax plus consumption tax) } * 70 \% \\
\end{array}$} & \multirow{2}{*}{$\begin{array}{l}\text { Postal Article Tax of } \\
\text { Cross-border } \\
\text { E-commerce } \\
2014(\%)\end{array}$} \\
\hline & $\begin{array}{l}\text { Added Value } \\
\text { Tax (\%) }\end{array}$ & $\begin{array}{l}\text { Consumption } \\
\text { Tax (\%) }\end{array}$ & $\begin{array}{c}\text { Comprehensive } \\
\text { Tax (\%) }\end{array}$ & \\
\hline Milk Powder for Baby & 17 & 0 & 11.7 & 15 \\
\hline Baby Food & 17 & 0 & 11.7 & 15 \\
\hline Honey, bird nest & 17 & 0 & 11.7 & 15 \\
\hline $\begin{array}{l}\text { Clothes, Trouser, } \quad \text { Underwear } \\
\text { (Textile) }\end{array}$ & 17 & 0 & 11.7 & 30 \\
\hline Shoes and boots & 17 & 0 & 11.7 & 30 \\
\hline Electronic product & 17 & 0 & 11.7 & 30 \\
\hline Face cream, and mask & 17 & 0 & 11.7 & 30 \\
\hline Shampoo and body wash & 17 & 0 & 11.7 & 30 \\
\hline $\begin{array}{l}\text { Foundation, lip balm, eyebrow } \\
\text { pen }\end{array}$ & 17 & 30 & 32.9 & 60 \\
\hline $\begin{array}{l}\text { Watch (import duty-paid price } \\
<10000 \text { RMB) }\end{array}$ & 17 & 20 & 25.9 & 30 \\
\hline $\begin{array}{l}\text { Watch (import duty-paid } \\
\text { price } \geq 10000 \text { RMB) }\end{array}$ & 17 & 30 & 32.9 & 60 \\
\hline Alcohol & 17 & 50 & 46.9 & 60 \\
\hline Cigarette and Cigar & 17 & 50 & 46.9 & 60 \\
\hline
\end{tabular}

Table 3 Duty-paid price list of imported products of the People's Republic of China after April 6th, 2016.

\begin{tabular}{lll}
\hline & Item Name & $\begin{array}{l}\text { Tax } \\
\text { Rate \% }\end{array}$ \\
\hline 1 & $\begin{array}{l}\text { Foods (including milk powder and healthcare product), drinks, publication, books } \\
\text { and newspaper, lantern slide, educational movie, video camera recorder, video } \\
\text { tape, original tape, gold, silver and related product, calculator, camera, digital } \\
\text { camera and other information technical products }\end{array}$ \\
2 & $\begin{array}{l}\text { Textile and finished product, skincare product (body wash and care product, } \\
\text { cleaning product and skincare product), suitcase and shoes, watch, clock } \\
\text { (including parts and accessories), golf ball and gear, small home appliance, }\end{array}$ \\
camera and bicycle & $\begin{array}{l}\text { Cigarette, alcohol, high-end watch (duty-paid price of more than 10000 RMB), } \\
\text { cosmetics (aromatic cosmetics, lip, eye and nail cosmetics such as lip stick, eye 60\% } \\
\text { shadow and finger nail oil, cosmetic powder and cosmetics of unique function) }\end{array}$ \\
\hline
\end{tabular}

Note: Please check the 'the Imported Product Category of the People's Republic of China' and 'the Notice of Duty-paid Price list of Imported Products of the People's Republic of China' (File No.25, 2016) issued on April 6th and implemented on 8th, 2016 for more detailed products. 
In addition, the No.26 Announcement has adjusted the postal article tax to personal item. Based on product category, the postal article tax levels have been changed from the $10 \%, 20 \%, 30 \%$ and $50 \%$ in 2014 to $15 \%, 30 \%$ and $60 \%$ in 2016 respectively (more details in Table 3). At the same time, the postal article tax remains the starting amount of taxation of 50 RMB.

Generally speaking, 'the Notice of Supervision upon the Import and Export Goods and Items of Cross-border Trading E-commerce' is a mile stone symbolizing the development of China's cross-border e-commerce. For the first time, it clearly categorizes the products of purchasing on one's behalf and on-line shopping and the imported personal belongings, which is the earliest customs policy especially for the cross-border e-commerce. Therefore, this essay will focus on the deep comparison and interpretation upon the above notice and 'the Notice of Supervision upon the Import and Export Product of Cross-border E-commerce Retail Sales’ of 2016.

\section{Existing Problems in the "Old Polity" ----Postal Article Tax of Cross-Border E-commerce of China}

China has two purposes of collecting postal article tax from products of on-line shopping through direct sales import and bonded import. First is to encourage and promote the development of cross-border importing e-commerce with comparatively lower postal article tax. Second is to lead more consumers to purchase overseas products through the official supervising platform of customs as a 'sunny' channel and achieve more effective supervision of customs. However, the rate of postal article tax differs from that of general goods trading. As a result, the postal article tax implemented as a trial from 2014 has faced a lot of problems.

\subsection{Postal Article Tax in Trial is not Compatible with the Development of Cross-Border E-commerce}

According to the regulation of taxation regulation of the Customs, the imported mailing items include personal belongings and commercial goods and should be applied different custom procedures based on their nature. At present, the direct sales of cross-border e-commerce mostly deals with items of small size, large number and high price in mail package, whose nature are hard to be identified, bringing difficulty to the supervision of taxation. On the other hand, the bonded import of cross-border e-commerce mostly deals with daily-used products of large size and low price. In the process of clearance, they leave the bonded area as personal items, bringing a large loss to the national taxation.

In addition, according to the 'Customs Law', China Customs applies different clearance procedures and management measures to different items and goods in supervision. From the point of view of product nature, items in cross-border e-commerce have the nature of commercial goods and should be taxed as goods according to customs regulation. Though the postal article tax for imported products of small amount in cross-border e-commerce is a trial measure, the difference between imported goods and personal items in cross-border e-commerce is confused by the original nature of products in the postal article taxation, hindering effective statistics of customs toward e-commerce. ${ }^{[2][3]}$

\subsection{The Imported Products of On-line Shopping Conflict with Products of Traditional Sales Channel in Price}

As a result of different tax rate of goods and personal items, the imported products taxed as items in cross-border e-commerce differ in price from the imported trading goods in traditional cargo. Let's take five hot sale products in 2014 for example, such as food for baby and children, clothes, 
skincare product and beauty cosmetics. The postal article tax rate for baby and children food is $10 \%$, but becomes tariff of $5 \%$ plus added value tax of $17 \%$ if imported by general trade (more details in Table 4). The postal article tax rate of health care products is $10 \%$, but becomes tariff of around $15 \%$ plus added value tax of $17 \%$ if imported by general trade. The postal article tax rate of electronic product is $10 \%$ or $20 \%$ based on minor categories, but becomes tariff of $10 \%$ to $30 \%$ plus added value tax of $17 \%$ if imported by general trade. The postal article tax rate of clothes is $20 \%$, but become tariff of $7 \%$ to $20 \%$ plus added value tax $17 \%$. The postal article tax rate of skin care and beauty cosmetics is as high as $50 \%$, but is still lower than the total amount of tariff of $10 \%$ plus added value tax of $17 \%$ plus consumption tax of $30 \%$ if imported by general trade.

With the above comparison of import tax of different products, it is clear that the tariff of product imported by general trade is higher than the postal article tax rate (more details in Table 4). As the cross-border e-commerce develops, the difference of tax rate by difference import channel not only leads to the conflict of products price, but also lowers the financial income dramatically.

Table 4 Comparison of import tariff in general trade and postal article tax for common products before april 6th, 2016.

\begin{tabular}{|c|c|c|c|c|}
\hline \multirow{2}{*}{ Product Name } & \multicolumn{3}{|c|}{ Import by General Trade } & \multirow{2}{*}{$\begin{array}{l}\text { Postal Article Tax } \\
\text { of Cross-border } \\
\text { E-commerce (\%) }\end{array}$} \\
\hline & MFN Tariff (\%) & $\begin{array}{l}\text { Added Value } \\
\text { Tax (\%) }\end{array}$ & $\begin{array}{l}\text { Consumption } \\
\text { Tax }(\%)\end{array}$ & \\
\hline Milk Powder for Baby & 5 & 17 & 0 & 10 \\
\hline Baby Food & 5 & 17 & 0 & 10 \\
\hline Honey, bird nest & $15-25$ & 17 & 0 & 10 \\
\hline Garment & $\geq 14$ & 17 & 0 & 20 \\
\hline Shoes and boots & 12 & 17 & 0 & 20 \\
\hline Electronic product & $10-30$ & 17 & 0 & $10-20$ \\
\hline Face cream, and mask & 2 & 17 & 0 & 50 \\
\hline Shampoo and body wash & $6.5-10$ & 17 & 0 & 10 \\
\hline $\begin{array}{l}\text { Foundation, lip balm, eyebrow } \\
\text { pen }\end{array}$ & 10 & 17 & 30 & 50 \\
\hline $\begin{array}{l}\text { Watch (import duty-paid price } \\
<10000 \text { RMB) }\end{array}$ & $\geq 11$ & 17 & 20 & 20 \\
\hline $\begin{array}{l}\text { Watch (import duty-paid } \\
\text { price } \geq 10000 \text { RMB) }\end{array}$ & $\geq 11$ & 17 & 30 & 30 \\
\hline Alcohol & 10 & 17 & 50 & 50 \\
\hline Cigarette and Cigar & 25 & 17 & 50 & 50 \\
\hline
\end{tabular}

Note: MFN tariff is based on the standard implemented on June $1^{\text {st }}, 2015$.

\section{Comparison of "New" Comprehensive Tax and "Old" Postal Article Tax of Cross-Border" E-commerce}

The remarkable difference between the comprehensive tax and the old postal article tax in cross-border e-commerce leads to a large change towards the taxation amount of imported products. The following will be a deep analysis of how comprehensive tax influences the imported products at different price levels.

\subsection{The Influence of New Tariff Policy towards Low Price Products of Postal Article Tax below 50 RMB}

According to the old tariff policy of 2014, single imported product below 1000 RMB is applied customs clearance as personal belongings and postal article tax, and product with tax amount of 50 
RMB or below is exempted from taxation, especially for products with postal article tax rate of only $10 \%$ such as food, baby and children products and health care products. Therefore, consumers tend to purchase products of single price below $500 \mathrm{RMB}$ which are of bonded import.

The new policy of 2016 cancels the regulation that single product with tax amount of $50 \mathrm{RMB}$ or below is exempted from taxation, and applies comprehensive tax of $11.7 \%$ to foods and baby and children products (more details in Table 2). The implementation of new policy remarkably increases the tax of low price products and raises the import requirement of low price products imported by cross-border e-commerce. However, the policy of comprehensive tax regulates that products imported by cross-border e-commerce enjoy tax exemption and are only applied $70 \%$ of the added value tax plus consumption tax. Therefore, when compared with products of general trade, low price products imported by cross-border e-commerce are still applied lower taxation. As a result, among products of traditional sale channel and those imported by cross-border e-commerce, consumers still tend to choose low price products of lower taxation.

\subsection{The Influence of New Tariff Policy towards Middle Class Products between 500 RMB and 1000 RMB}

The old tariff policy regulates that single product of tax amount above $50 \mathrm{RMB}$ but with a price lower than 1000 RMB is applied postal article tax, namely tax level of $10 \%, 20 \%, 30 \%$ and $50 \%$ to products imported by cross-border e-commerce according to their categories. Products of price between 500 RMB and 1000 RMB are mostly clothes, shoes and boots, electronic products and cosmetics. According to the personal postal article tax rate of Table 1, the tax rate for clothes, shoes, boots and electronic product is $20 \%$ or $30 \%$, and the tax rate of cosmetics is $50 \%$.

According to the new tariff policy of 2016 (more details in Table 2), the comprehensive tax rate of clothes, shoes and boots and electronic product is $11.9 \%$, and $32.9 \%$ for the cosmetics. When compared with the personal postal article tax, the taxation of these products is remarkably lower. Therefore, the new policy dramatically lowers the taxation amount of products with price between $500 \mathrm{RMB}$ and $1000 \mathrm{RMB}$ imported by cross-border e-commerce.

\subsection{The Influence of New Tariff Policy towards Middle Class Products between 1000 RMB and 2000 RMB}

The old tariff policy of 2014 regulates that single product above 1000 RMB is taxed as general trade import. Middle and high end watches, cigarette, alcohol and skin care products are applied tariff of 58\% to 92\%. Even according to the regulation that imported product above 1000 RMB of being single, inseparable and confirmed to be personal use by the customs can be applied clearance as personal belonging, such as watches, some middle and high end products of being inseparable are still applied postal article tax of 50\%.

On the basis of zero tariff applied to products imported by cross-border e-commerce, the new tariff policy of 2016 regulates that imported products are applied $70 \%$ of the added value tax plus consumption tax as general trade, and the limit of single transaction amount rises from $1000 \mathrm{RMB}$ to 2000 RMB. Middle and high end products between 1000 RMB and 2000 RMB are only applied comprehensive tax of $25.9 \%$ to $46.9 \%$ (more details in Table 2). From the comparison of new and old tax rate, it is obvious that middle and high end products between $1000 \mathrm{RMB}$ and $2000 \mathrm{RMB}$ are now applied much lower import tax.

\subsection{The Influence of New Tariff Policy towards High-end Products above 2000 RMB}

High-end and luxurious products above 2000 RMB are applied customs clearance as general 
import trade and full amount tariff of 58\% to 92\% according to both the old and new tariff policy. Therefore, the comprehensive tax of new policy has a limited influence over the luxurious products imported by cross-border e-commerce. However, the implementation of new policy fully adjusts the personal postal article tax rate in which the tax rate standard is raised, remarkably affecting the import of luxurious products in the name of personal belongings. According to the old standard of postal article tax, the import of high-end watch and luxurious products is applied tariff of $30 \%$ or $50 \%$. In the new standard of postal article tax rate, if luxurious products are still imported as 'personal belongings', they will be separated and applied postal article tax of $60 \%$. Therefore, the measures of increasing the postal article tax rate in 2016 help to prevent cross-border e-commerce goods from the import clearance in the name of personal belongings to a large extent.

\section{Functions of "New "Policy--Cross-Border E-commerce Comprehensive Tax}

\subsection{Promoting the Development of Enterprise-based Bonded Import (B2B2C) Model}

The proposed e-commerce comprehensive tax will effectively curb C2C and promote the development of cross-border B2B2C. The comprehensive tax rate in the updated policy is significantly lower than corresponding import tax on goods. Besides, the regulation that 'for a single shopping of more than 2,000 RMB, the tariff should be collected in accordance with the general trade pattern' will lead consumers to prefer purchasing overseas goods by means of cross-border e-commerce instead of traditional commerce. In particular, compared with direct sales import (B2C) model, bonded import (B2B2C) model has many unique advantages like timely return and exchange, quality assurance and low transportation cost, which can not only attract consumers of B2C model, but also attract consumers of 'gray zone' purchasing on one's behalf and promote the crowding effect of B2B2C model on C2C and even B2C. Therefore, it can be seen from regulations in the new tariff policy that Chinese government's attitude of encouraging both $\mathrm{B} 2 \mathrm{C}$ and B2B2C has been transformed into focusing on B2B2C with B2C as a supplement. That is, the government has changed from encouraging the development of multiple types of cross-border e-commerce to focusing on supporting B2B2C e-commerce. ${ }^{[9][10]}$

Based on the process of B2B2C cross-border e-commerce, it can be split into two parts, overseas $\mathrm{B} 2 \mathrm{~B}$ and domestic B2C. From a global perspective, China's encouraging the development of B2B2C e-commerce is consistent with the development trend of e-commerce in Europe and the U.S. In 2014, US B2B e-commerce sales reached \$2.1278 trillion and B2C retail sales reached \$297.2 billion, with B2C accounted for only $12.26 \%$ of the total e-commerce sales. UK B2C sales amounted to 31 billion pounds in 2014, which accounted for only 5.4\% of its total e-commerce sales. Obviously, B2B model occupies a dominant position in global e-commerce. Therefore, encouraging the development of B2B2C as a new trade format not only conforms to international development trends, but also enables B2C bonded zones in China to effectively monitor cross-border e-commerce activities.

\subsection{Effectively Preventing the Entry of Small-scale Products Bought Via Cross-Border E-commerce Platforms in the Name of 'Personal Belongings'}

In China's old postal article tax of cross-border e-commerce, there was a significant difference between postal article tax of goods and the taxation of imports from general trade. Take household electric products such as electric razors as an example. A $10 \%$ postal article tax was levied on personal belongings entering China by post and express delivery, while an import duty of 32\% (tariff rate of $15 \%$ and import value-added tax of $17 \%$ ) was required on goods imported by express shipments or general trade methods. The difference between tax rates was $22 \%$. Due to the great 
difference in tax rates, cross-border e-commerce operators often divided goods into multiple batches or even single items, and delivered them in parcels or shipments. In this way, the nature of the goods was changed into personal belongings, thus evading customs inspections and tariff collection.

The updated policy on cross-border e-commerce introduced in 2016 substantially increased the tax rate for postal article tax. The adjusted postal article tax rate of corresponding products is higher than their comprehensive tax rate. As a result, the previous 'smuggling' through parcels in the name of 'personal belongings' will be effectively curbed, and difficulties in customs clearance supervision of cross-border e-commerce will be effectively improved.

\subsection{Realizing Effective Customs Statistics on E-commerce Import}

In July 2014, the General Administration of Customs of China (GAC) issued 'the Announcement on Regulatory Matters Concerning the Entering and Leaving China of Goods and Articles Purchased via Cross-border E-Commerce Platforms', requiring e-commerce companies or individuals, payment companies and logistics companies to submit relevant orders, payment and logistics information to the customs while reporting on imported goods and articles. In order to tie in with the statistics of import data, GAC promulgated 'the GAC Announcement on Adding Codes of Customs Supervision Methods' (File No.12, 2014) in February 2014 ${ }^{[5]}$ and 'the GAC Announcement on the Addition of Codes for Customs Supervision Methods' (No. 57, 2014) in July $2014^{[6]}$, proposing to add 9610 codes for cross-border e-commerce and 1210 codes for bonded cross-border e-commerce. However, in order to avoid tax for customers, e-commerce operators have bypassed code registration for a large number of cross-border e-commerce imports and had the goods enter customs in the name of personal belongings, which added the difficulty of customs statistics.

After the updated tariff policy was implemented in 2016, under the control of comprehensive tax and the latest tax rate for postal article tax, cross-border e-commerce operators could no longer evade high taxation in the name of personal belongings. Therefore, commodities will enter China through the customs' unified supervision platform. The Customs can not only complete effective statistics on cross-border e-commerce imports, but also accurately assess the effects of cross-border e-commerce on China's import and export and overall economy.

\subsection{Effectively Increasing the Customs Revenue of China Customs}

According to the old postal article tax of cross-border e-commerce in 2014, most of the goods eligible for exemption are foods, baby products and health products of less than $500 \mathrm{RMB}$. Among them, baby and children foods and products were relatively popular in China. Take baby and children milk powder as an example. In 2008, China's output of baby and children milk powder was 532,300 tons. Affected by the 2008 'Trichloro Cyanamide' incident, in 2009, China's baby and children milk powder production declined sharply and the output was 411,600 tons, showing a year-on-year decrease of $24.55 \%$. Due to food safety problems and the much lower price of dairy products in the international market than that of China, China's milk powder import has shown significant growth in recent years. According to data of Chinese customs, in 2015, China imported 176,000 tons of baby and children formula milk powder, which was an increase of 55,000 tons and $45 \%$ to the 121,000 tons in 2014. In 2016, China imported 604,200 tons of milk powder, up by $10.4 \%$ over the same period. In addition, the two-child policy that was fully liberalized in 2016 will also push up the demand for maternal and child products. Therefore, continuing to adopt zero-tariff policies on such products will exacerbate the loss of tax revenue in China.

The 2016 new tariff policy eliminated the preferential of 'taxation exemption for goods with a 
tax amount under 50 RMB (including 50 RMB)', and levied $11.7 \%$ of cross-border e-commerce comprehensive tax on import of small items less than 500 RMB. According to '2016-2017 Report on the Development of China's Cross-border E-commerce Import' released by China Electronic Commerce Research Center, goods most favored by cross-border e-commerce consumers in 2016 included beauty care products, maternal and child products, shoes and clothing, foods, jewelry and bags. Among them, beauty care and maternal and child products less than 500 RMB were still the most popular consumer goods. Besides, the government's support of B2B2C model will also encourage more consumers to purchase low-value daily goods. Therefore, the collection of e-commerce comprehensive tax on low-value goods will significantly increase China's fiscal revenue.

\section{References}

[1] Feng, R. (2015) Research on Customs Tariff Supervision of China's Cross-Border E-commerce. International Economics and Trade Research, 2, 77-85.

[2] Feng, R. The situation of E-commerce Development of China. [C].Bule Book of Foreign Tradeand Economic of Guangdong (2014-2015).social sciences academic press.2015.

[3] Guo, J. (2016) the 30th Statistical Report on Internet Development in China' and 'the 31st Statistical Report on Internet Development in China. China Internet Network Information Center.

[4] Office for National Statistics in UK.(2014)E-commerce and ICT Activity.

[5] General Administration of Customs of the PRC. (2014).GAC Announcement No. 12 in 2014 (Announcement on Adding Codes of Customs Supervision Methods).

[6] General Administration of Customs of the PRC.(2014)GAC Announcement No. 57 in 2014 (Announcement on the Addition of Codes for Customs Supervision Methods).

[7] General Administration of Customs of the PRC. (2014)GAC Announcement No. 56 in 2014'the Announcement of Supervision on the Import \& Export Goods and Items in Cross-border E-commerce.

[8] General Administration of Customs of the PRC. (2016)GAC Announcement No. 40 in 2016. 'the Announcement of Imported Product List of Cross-border E-commerce Retail Sales.

[9] U.S.Customs and Border Protection.(2014)Commercial Samples and Printed Advertising Materials . 